\title{
THE WORLD AFTER THE FINANCIAL CRISIS - WHO SHOULD BE RESPONSIBLE FOR INTERNATIONAL FINANCIAL SUPERVISION?
}

\author{
Bartosz Ziemblicki*
}

\section{Introduction}

The world financial crisis 2007-2009 devastated the global economy. Market forces have failed and the need to regulate the financial sector has been revealed. The interdependencies of economies in different states proved that in order to prevent future crises it is critical to coordinate the actions of all interested parties, which in turn requires international regulation. This article seeks to explore who should be responsible for international financial supervision. Prior to answering this question, it is necessary to determine the causes of the crisis, the purposes of supervision and the current state of regulation.

Chair of Economic Law at the Wroclaw University of Economics; partner at ZKZ Legal Chamber. 


\section{The Causes of the Crisis}

\subsection{The List of Failures}

The symbolic apogee of the crisis was the collapse of the Lehman Brothers on 15.9.2008. This is likely the reason why the media focused on the greed of Wall Street Bankers in explaining the causes of the crisis. However, it is only part of the whole picture and economists highlight many different causes of the crisis.

Lastra and Wood made an effort to summarize those causes of the crisis in the United States that are most commonly agreed upon, and then divided them into three categories. They listed: ${ }^{1} 1$. credit expansion in the US financed by China (persistent imbalance of payments), 2. interest rates that were too low (easy money), which resulted in an asset-price bubble, 3. weak supervisory rules in liquidity and accounting, 4. too-big-to-fail philosophy (moral hazard incentives fuelled by the bailout of Fannie Mae and Freddie Mac), 5. excessive securitization (resulting in subprime mortgages), 6. insufficiently regulated market actors (credit-rating agencies, hedge funds), 7. corporate failures (pay structures mismanaging bonuses, relationships between managers and shareholders), 8. decline in lending standards (credit expansion unbalanced by bank deposits), 9. unbridled greed (contributing to all other factors), 10. faulty economic theories (unquestioning faith in self-regulatory markets). The first four factors are government failures, whereas market failures and the last two were economists' failures. The irresponsible promotion of home ownership in the US cost most of the potential beneficiaries their life savings.

The most direct cause of the crisis was probably insufficient capital requirements for banks, bolstered by moral hazards created by bailouts. ${ }^{2}$ Moral hazard refers to

1 R.M. Lastra, G. Wood, The Crisis of 2007-09: Nature, Causes and Reactions, 'Journal of International Economic Law' 2010, vol. 13, no 3, p. 531, at pp. 537-544.

2 H.S. Scott, Reducing Systemic Risk through the Reform of Capital Regulation, 'Journal of International Economic Law' 2010, vol. 13, no 3, p. 763, at p. 763. 
a situation where someone can reap the reward from their action when things go well, but does not suffer the full consequences when things go badly. Hence, investors do not have to exercise due diligence since they would expect a bailout in the case of default, or for that matter, debtor countries can choose to pursue risky economic policies with the expectation that they will not have to pay the full costs of their debts and investors will not lose the full amount invested if a financial crisis occurs. $^{3}$

Capital is the first line of defence when losses occur. Inadequate capital poses a systemic risk to financial markets, because markets are in danger when the largest actors are unable to meet their obligations. The Securities and Exchange Commission (SEC) implemented Basel II-based rules on capital, which allowed the top five major investment banks to achieve leverage of over 30 to $1 .^{4}$ This was the major factor contributing to the failures of Lehman Brothers, Bear Stearns and Merrill Lynch. ${ }^{5}$ At the same time, the deposit banks were leveraged at 13 to $1 .{ }^{6}$ The asset bubble was fed by the availability of easy money (high saving countries like China and India exported capital to low saving countries like the USA and the UK).

\subsection{The Transparency Problem}

Asymmetric information emerges when "one party to a financial contract does not have the same information as the other party". ${ }^{7}$ Transparency is very important, because markets fear uncertainty more than poor results. ${ }^{8}$ The US Supreme Court Justice Louis Brandeis once

3 S.D. Sharma, Constructing the New International Financial Architecture. What Role for the IMF?, 'Journal of World Trade' 2000, vol. 34, no 3, p. 47, at p. 51, footnote 24.

4 Committee on Capital Markets Regulation, The Global Financial Crisis: A Plan for Regulatory Reform, (2009), at p. 60, http://capmktsreg.org [last accessed on 30.11.2013].

5 Joint Economic Committee Majority Staff, From Wall Street to Main Street: Understanding How the Credit Crisis Affects You, 2008, http://www.heraca.org/downloads/ HowDoestheCreditCrisisImpactYou_1008.pdf [last accessed on 30.11.2013].

6 Committee on Capital Markets Regulation, The Global..., 2009, at p. 60.

7 S.D. Sharma, op. cit., footnote 24.

8 H.S. Scott, op. cit., at p. 776. 
wrote: "Publicity is justly commended as a remedy for social and industrial diseases. Sunlight is said to be the best of disinfectants; electric light the most efficient policeman". ${ }^{9}$ Transparency is a precondition for building confidence. This is why transparency has become a priority on the agendas of international financial regulators after the crisis. ${ }^{10}$ Furthermore, accountability depends on reliable information.

Transparency includes comprehensibility. Information that is overly sophisticated is as useless as a lack of information. As Kaufmann and Weber point out, according to the report of the Swiss Financial Markets Supervisory Authority, the level of complexity of the Basel II model exceeded the capacities not only of banks' managements, but also of the supervisors. ${ }^{11}$

Unlike in Europe, in the United States the banking sector and securities sector were largely separated - Banking was substantially regulated, while securities remained unsupervised. ${ }^{12}$ It has been so ever since the Glass-Steagall Act of 1933 entered into force. As a result, non-banking institutions began to compete with banks, offering similar products, but with higher yields due to lower costs. The banking industry got frustrated, since its safety and transparency rules made them uncompetitive. ${ }^{13}$ Wall Street came to be known as the shadow banking system, ${ }^{14}$ selling mortgage-backed securities, asset-backed commercial papers and collateralized debt obligations, with inadequate disclosure about the associated risks. ${ }^{15}$

9 L.D. Brandeis, What Publicity can do, [in:] 'Other People's Money: and how the Bankers use it', Mansfield Centre: Martino Publishing, 2009, first published 1914 by McClure Publications, at p. 92.

10 Ch. Kaufmann, R.H. Weber, The Role of Transparency in Financial Regulation, 'Journal of International Economic Law' 2010, vol. 13, no 3, p. 779, at p. 780 and 783.

11 Ibid. at p. 780 and 789.

12 R. Bismuth, Financial Sector Regulation and Financial Services Liberalization at the Crossroads: The Relevance of International Financial Standards in WTO Law, 'Journal of World Trade' 2010, vol. 44, no 2, p. 489, at p. 491.

13 D.C. Langevoort, Global Securities Regulation after the Financial Crisis, 'Journal of International Economic Law', 2010, vol. 13, no 3, p. 799, at pp. 802-803.

14 See Ch.K. Whitehead, Reframing Financial Regulation, 'Boston University Law Review' 2010, vol. 90, no 1, p. 2.

15 D.C. Langevoort, op. cit., p. 808. 


\subsection{The Government and the Ranking Agencies Failures}

As mentioned above, among the causes of the 2007-2009 crisis the experts point mostly at excessive and risky speculation on Wall Street, malfunctioning bankers' incentives and abuses in the mortgage markets. These are symptoms of market failures in unregulated markets. However, according to Steve Charnovitz, the government failures are to blame next to market failures. ${ }^{16}$

The direct cause of the crisis was the decline of the value of mortgage bonds, but was enhanced by the government help. The US government bailout saved Fannie Mae and Freddie Mac, as well as Bear Stearns and AIG. By doing so, it discouraged other banks from foreclosing, as they would otherwise do. The so-called too-big-to-fail corporations received cheap capital from the US government. They expected to be bailed out and made no effort to maintain market discipline. ${ }^{17}$

As a reaction to the crisis, the US Congress passed the Dodd-Frank Act. However, it does not contain the necessary reforms, since it focused on establishing a Financial Stability Oversight Council of 15 members, whose task is to identify risks to financial stability. Since the Council includes no foreign regulators, academic economists or consumers' representatives, Charnovitz describes this group as "bureaucrats... unlikely to be able to predict and manage systemic risk". ${ }^{18}$

Another sin of the US government was its excessive reliance on credit rating agencies. Major rating agencies (Fitch, Standard \& Poor's, Moody's) contributed to the crisis by giving undeservedly high grades to financial products. Many of the insurance policies against the failure of mortgages were rated as AAA. When housing prices decreased, financial institutions started to fall. A liquidity crisis turned into a solvency crisis. ${ }^{19}$

16 S. Charnovitz, Addressing Government Failure through International Financial Law, 'Journal of International Economic Law' 2010, vol. 13, no 3, p. 734, at p. 746.

17 Ibid., at pp. 747-748.

18 Ibid., at pp. 748-749.

19 R. M. Gadbaw, Systemic Regulation of Global Trade and Finance: a Tale of two Systems, 'Journal of International Economic Law' 2010, vol. 13, no 3, p. 551, at p. 556. 
The system is pathological, since agencies are financed by the issuers of financial products and not by their purchasers, which is an obvious conflict of interest. They instilled false confidence in both groups. ${ }^{20}$ One of the goals of the Dodd-Frank Act is to expand the regulation of the rating agencies. The idea of preventing the US regulators from relying too heavily on credit ratings in any regulation seems reasonable. ${ }^{21}$

\subsection{The Crisis Turns Global}

Even if the ignition of the crisis was originally located in the subprime mortgages sector of the US housing market, the crisis shortly became global. The reason for this is that the largest private financial institutions such as Citigroup, Goldman Sachs, J.P. Morgan Chase, Deutsche Bank, Credit Suisse or UBS are in fact global, with agencies, affiliations and assets all over the world. ${ }^{22}$

One should keep in mind that, unlike physical products and most services, financial products always feature a particular jurisdiction. Financial products do not occur in nature and are entirely social products that are inherently tied to capital. But at the same time, since capital is intangible it can be easily be relocated to any other jurisdiction. Therefore, if financial products are sold on an international market, they have both domestic and international character. ${ }^{23}$ Modern financial products feature extraterritoriality. This is why financial globalization began to challenge the assignment of monetary policy strictly to national authorities. ${ }^{24}$ This view is supported by the information and communication technology revolution, which resulted in highly mobile capital. ${ }^{25}$

20 D.C. Langevoort, op. cit., at pp. 808-810.

21 H.S. Scott, op. cit., at p. 767.

22 D.C. Langevoort, op. cit., at pp. 799-800.

${ }^{23}$ Ch. Tietje, M. Lehmann, The Role and Prospects of International Law in Financial Regulation and Supervision, 'Journal of International Economic Law' 2010, vol. 13, no 3, p. 663 , at p. 669 .

24 G. Hufbauer, D.D. Xie, Financial Stability and Monetary Policy: Need for International Surveillance, 'Journal of International Economic Law' 2010, vol. 13, no 3, p. 939, at p. 940.

25 S.D. Sharma, op. cit., at p. 62. 
The traditional model of financial supervision is a sectorial model: different state agencies investigate banking, insurance and securities firms. Since the 1980s cross-sectorial products and services occurred, supervision also began to become more cross-sectorial. ${ }^{26}$ Ultimately, most developed states adopted integrated financial supervision with one central agency. ${ }^{27}$ This step was made in the right direction and may be considered as progress; however the main modern problem with financial supervision is yet to be solved. Financial turmoils are no longer national (if they ever were). Financial markets of different states all over the world are more and more interdependent. Globalization brought us to a point where no state can feel safe about its financial stability, because of stringent internal financial supervision. A financial crisis in a huge economy (US, EU, Russia, China, Brazil etc.) affects the economies of not only its neighbours but also those of economic partners on other continents. ${ }^{28}$

According to Hufbauer and Wada, in the $20^{\text {th }}$ century $75 \%$ of major financial crises worldwide (12 out of 16) had important international repercussions. ${ }^{29}$ In the $21^{\text {st }}$ century, this number is likely to increase. Apart from large rescue packages from the international community, little has been done to prevent crises from occurring in the future. Public actions did not follow public statements. It should be added that the number of international financial transactions increases proportionally about ten times as fast as international trade transactions..$^{30}$ Despite this, the public penalties for financial mismanagement today are not much more severe than they were two decades ago. ${ }^{31}$

"If trade shocks are like strong winds, than financial shocks are like tornados". ${ }^{32}$ They affect the economy within weeks or even days. This is why quick responsive actions are critical. A major financial crisis occurs at

26 Ch. Tietje, M. Lehmann, op. cit., at p. 667.

27 E. Cervellati, E. Fioriti, Financial Supervision in EU Countries, Working Paper, http:// ssrn.com/abstract=873064 [last accessed on 30.11.2013].

28 Ch. Tietje, M. Lehmann, op. cit., at p. 668.

29 G. Hufbauer, E. Wada, Can Financiers learn from Traders?, 'Journal of International Economic Law' 1999, vol. 2, no 4, p. 567, at pp. 568-569.

30 Ibid., at p. 570.

31 Ibid., at p. 587.

32 Ibid., at p. 574. 
least once per decade. ${ }^{33}$ The crisis has shown how misguided the belief was that financial services in industrialized states are strict and adequate. ${ }^{34}$ The uncritical belief in the inherent efficiency of markets has been shattered. ${ }^{35}$ It also revealed that any financial crisis in one of the world's major economies immediately turns global and affects states all over the world.

When the crisis contagion spreads, it does not spare the innocent. Well-managed countries may suffer equally when the crisis hits them. When problems are global, responses need to be global as well. However, designing a financial architecture, so that it is responsive to international problems, is not an easy task. ${ }^{36}$

\section{The Purpose of International Financial Supervision}

\subsection{The Purpose of International Financial Regulation}

The ultimate goal of international financial regulation is financial stability. There are other secondary objectives, which include for example consumer protection, market integrity and the prevention of fraud ${ }^{37}$, but the priority is to minimize the chances of financial crises occurring in the future and also to limit their consequences when they do occur. Measures are needed both at the national and international levels. ${ }^{38}$ International trade and monetary surveillance are complementary actions. ${ }^{39}$ The development of international financial regulation does not preclude markets remaining open. On the contrary, open market economies fare much better in the long run.

33 Ibid., at p. 579.

34 P. Delimatsis, P. Sauve, Financial Services Trade after the Crisis: Policy and Legal Conjectures, 'Journal of International Economic Law' 2010, vol. 13, no 3, p. 837, at p. 839.

35 Ibid., at p. 840.

36 See R.H. Weber, Multilayered Governance in International Financial Regulation and Supervision, 'Journal of International Economic Law' 2010, vol. 13, no 3, p. 683.

37 L. Garicano, R.M. Lastra, Towards a New Architecture for Financial Stability: Seven Principles, 'Journal of International Economic Law' 2010, vol. 13, no 3, p. 597, at p. 599.

38 S. Hagan, Enhancing the IMF's Regulator Authority, 'Journal of International Economic Law' 2010, vol. 13, no 3, p. 955, at p. 956.

39 G. Hufbauer, D.D. Xie, op. cit., at p. 952. 


\subsection{The Concept of the International Financial Regulation}

A state technically cannot become insolvent, because it can always issue more money. When governments rely on this safeguard it is dangerous for the economy, which is why legal limitations in this regard are desirable. ${ }^{40}$ Since the introduction of a global currency in the next couple of decades is highly unlikely (to say the least), ${ }^{41}$ we should not consider it as an option, but rather seek other, more realistic, answers to the modern challenges of international financial and monetary law. The question to be answered is what role the law is to play in order to enhance international financial stability and prevent financial crises. In particular, an issue of great significance is to choose an institution to supervise international financial issues and to determine the scope of its mandate.

As Baltensperger and Cottier point out, since money was invented (first as coins, then as paper money), its creation directly linked to revenues, given differences between production costs and purchasing power. Over time, the private sector invented legal substitutes for states' money in different forms of financial products (demand deposits, highly liquid liabilities). The characteristic feature of those substitutes is their derivative nature and their convertibility into state currencies. Friedrich Hayek was amongst the most eager proponents of private money, seeing it as a cure for inflation which, in turn, he considered a consequence of government monopolies in monetary issues. ${ }^{42}$ However, if certain financial products compete with money, they may cause the same disasters that uncontrolled currencies sometimes do. In fact, the only way to keep the global economy safe is to directly control governments and indirectly control private institutions.

The idea of international financial supervision does not mean establishing strict surveillance of private financial institutions all over

40 E. Baltensperger, T. Cottier, The Role of International Law in Monetary Affairs, 'Journal of International Economic Law' 2010, vol. 13, no 3, p. 911, at p. 918.

41 Possible impact of the global currency on economy is beyond the scope of this article.

42 E. Baltensperger, T. Cottier, op. cit., at pp. 914-915. 
the world. It means the direct financial supervision of states, which in turn monitor private domestic actors. This surveillance would include, at a minimum, fiscal deficit limits, public debt-to-GDP rations, inflation and monetary policies, but also the enforcement of proper capital adequacy of private financial institutions. As for now, the only international (actually supranational) entity which has the authority to impose such limits on its members is the European Union, with fiscal deficit normally of $3 \%$ and public debt-to-GDP ratio normally at $60 \% .{ }^{43}$ As practice showed, the system failed - Greece, Spain, Italy, Portugal and Cyprus almost went bankrupt. Nonetheless, this is just a beginning, flawed due to weak enforcement. This may be the time of experiments and mistakes (some of them probably avoidable), but it is a step in the right direction.

Financial regulations must be revised and amended on a regular basis, to avoid becoming out of date. Two major regulatory regimes must be capital adequacy and the mandatory disclosure of information. ${ }^{44}$ Over seven decades ago, the economist Eugene Staley stated: "Economic problems can never be solved once and for all. The very essence of economic problems is change, readjustment to new conditions". ${ }^{45}$ The financial crisis of 2007-2009, which resulted in an increase of 34 million unemployed people worldwide, ${ }^{46}$ made governments reconsider existing supervision over international finance. The surveillance in place failed almost entirely, however modifications of the system require, on the one hand, balancing so as to keep markets' development dynamic and, on the other hand, ensuring the stability of financial markets. ${ }^{47}$ Equilibrium between those two values guarantees optimal economic conditions for market participants. What is critical is not only to wisely regulate financial markets, but also to ensure the enforcement of regulatory standards.

43 G. Hufbauer, E. Wada, op. cit., at p. 573.

44 M. Bagheri, Ch. Nakajima, Optimal Level of Financial Regulation under the GATS: A Regulatory Competition and Cooperation Framework for Capital Adequacy and Disclosure of Information, 'Journal of International Economic Law' 2002, vol. 5, no 2, p. 507, at p. 507.

45 E. Staley, World Economy in Transition, New York, Council on Foreign Relations 1939, at p. 300.

46 ILO, Global Employment Trends, January 2010, http://www.ilo.org [last accessed on 30.11.2013], at p. 9.

47 Ch. Tietje, M. Lehmann, op. cit., at p. 663. 
The advantages of international regulation probably outweigh its weaknesses, yet those weaknesses are not to be forgotten and overlooked. One shortcoming is that universal regulation eliminates regulatory competition among states, which serve as laboratories to verify different supervisory mechanisms. Another drawback is that common regulation also poses the potential threat of having devastating effects on the global economy if it transpired to be flawed (no safe havens would exist). ${ }^{48}$

\subsection{Common Proposals for What to Change}

Among the most common suggestions on how to improve financial predictability and stability are domestic solutions. They include propositions to supervise actors such as hedge funds, private equity funds, credit rating agencies and too-big-to-fail financial firms. Enhanced capital adequacy and liquidity requirements, along with the regulation of bankers' remuneration, mortgage down-payment requirements, central clearing houses for derivatives, limiting credit card debt, global accounting standards and the reporting of individual transactions to trade repositories are also often mentioned. In most cases, the focus is on macro-prudential supervision. ${ }^{49}$

Furthermore, governments should not bail out endangered banks so that the holders suffer significant losses. They should also make it clear in advance (and keep to it) what is covered by a public safety net, and what is not. This will limit the moral hazard. In addition, financial managers should be severely punished for mismanagement. ${ }^{50}$ Banks should be forced to keep reasonable capital adequacy. There is also a need for an international supervisor, which would execute a system of early warning about excessive short-term capital inflows (financial bubbles).

Garicano and Lastra suggest seven interesting improvements to the existing international financial architecture. They call for 1 . integrated supervision for banking, securities and insurance (synergy and coordination

48 Ibid., at pp. 679-680.

49 Ibid., at pp. 672-674; also G. Hufbauer, D.D. Xie, op. cit., at p. 940 and 951.

50 G. Hufbauer, E. Wada, op. cit., at p. 588. 
being more important than specialization, creativity and innovation), 2. central banks to accept the macro-prudential supervisory function (the lender of last resort role), 3. macro-supervisor to have direct authority over enforcement (when micro-supervision fails), 4. systemic risk supervisor to be accountable for its actions (reconciling institution's independence with democratic legitimacy), 5. long-term incentives and accountability of employees in supervisory agency, 6. accountability of executives at banks to limit the moral hazard (excessive risk taking), 7. changing current international financial system to be more hierarchical and centralized (with the IMF on the top). ${ }^{51}$ Those propositions include reforms on both domestic and international levels, which complement one another.

\section{Current State of Regulation and Typical Supervision Instruments}

\subsection{The Dispersion of International Financial Law}

The focus of international economic law was on trade regulation and investment. ${ }^{52}$ Therefore, there isn't much rule of law in international finance. The same is true for monetary issues - after the abandonment of the fixed exchange rates, there was little left to regulate in terms of substantive (as opposed to procedural) law.

International trade regulation is about liberalization, while international monetary and financial law is about stabilization. ${ }^{53}$ That is why non-discrimination is the central rule of international trade, yet it is much less important in monetary and financial law. ${ }^{54}$ It is worth noting that, within the non-discrimination rule, the customary international law applying to international organizations includes most favoured nation rule (MFN), but not the national treatment rule (NT). ${ }^{55}$

51 L. Garicano, R.M. Lastra, op. cit., at p. 597 and ff.

52 E. Baltensperger, T. Cottier, op. cit., at p. 927.

53 G. Hufbauer, E. Wada, op. cit., at p. 569 ff.

54 E. Baltensperger, T. Cottier, op. cit., at p. 932.

55 Ibid., at p. 934. 
International financial regulation is all but comprehensive. In particular, new products of financial markets are usually not covered by any international surveillance mechanisms. Those mechanisms focus on the quality of financial actors, information asymmetries, market behaviour or market infrastructure. ${ }^{56}$

The stability of exchange rates is a precondition for well-functioning markets and state economies, ${ }^{57}$ as is the predictability and transparency of financial products and services. However, unlike international trade, international financial and monetary issues are hardly regulated by law. States traditionally seemed to consider financial law as a purely domestic issue and tie it to the concept of national sovereignty, similar to tax law. ${ }^{58}$ The euro currency is to date the only example in international affairs of ceding monetary sovereignty to an international (supranational) organization. Even such an icon of liberal economy as Milton Friedman defends states authority in the area of finance, while praising free competition in trade. ${ }^{59}$ This attitude was directly expressed by the US Treasury Secretary John Connally, who said to European finance ministers in 1971: "The dollar is our money and your problem" ${ }^{60}$ For similar reasons, it is argued that also private financiers "hate sunshine". ${ }^{61}$

Economics is global and politics are local. Governments appreciate their sole authority to borrow and lend money, subsidize or redistribute in the manner they like. They are unwilling to take responsibility for how their financial policies affect other states. ${ }^{62}$ As Gadbaw has noted, the world of finance shows an almost pathological antipathy to regulation. The fact that we have just witnessed the most dramatic economic event of our generation ${ }^{63}$ has thus far not altered that assessment.

56 Ch. Tietje, M. Lehmann, op. cit., at p. 665.

57 E. Baltensperger, T. Cottier, op. cit., at p. 911.

58 R.M. Lastra, Legal Foundations of International Monetary Stability, Oxford 2006, at pp. 4-5.

59 M. Friedman, Essays in Positive Economics, Chicago 1953, at p. 217.

60 See G. Hufbauer, D.D. Xie, op. cit., at p. 940.

61 G. Hufbauer, E. Wada, op. cit., at p. 586.

62 S. Charnovitz, op. cit., at p. 755.

63 R. M. Gadbaw, op. cit., at p. 573. 


\subsection{The Interdependencies between Branches of International Economic Law}

Monetary and financial regulations are strictly linked. Low interest rates result in high risk-taking behaviour ${ }^{64}$ and fast credit growth causes financial crises. ${ }^{65}$ Easy money is dangerous for economies. ${ }^{66}$

Monetary policies traditionally focused on keeping inflation low within a desired range of $2-3 \% .{ }^{67}$ States that actively fought inflation generally achieved lower inflation levels and higher GDP growth rates. ${ }^{68}$ But, in doing so, they often forget about another purpose of monetary policy, which is financial stability and they were unable to prevent crises. Even though some claim that financial crises are a tool to bring to an end weak companies, the social costs of such selection are usually very high. ${ }^{69}$

In international trade, there is a global coordination institution - the World Trade Organization. In monetary affairs, there is the International Monetary Fund. Both organizations have strong treatybased backgrounds, distinct legal personalities and universal membership, which give them authority and credibility. In finance, there is none. World finances are directed through inter-agency institutions (central banks, regulatory agencies and supervisors, finance ministers) and commitments are not even formally binding. ${ }^{70}$ The only global financial organization, in

64 See Y. Altunbas, L. Gambacorta, D. Marues-Ibanez, Does Monetary Policy Affect Bank Risk-taking?, BIS Working Papers no 298, March 2010, http://www.bis.org/publ/work298. htm [last accessed on 30.11.2013].

65 See M. Schularick, A.M. Taylor, Credit Booms Gone Bust: Monetary Policy, Leverage Cycles and Financial Crises, 1870-2008, National Bureau of Economic Research Working Paper no 15512, November 2009, http://www.nber.org/papers/w15512 [last accessed on 30.11.2013].

66 G. Hufbauer, D.D. Xie, op. cit., at p. 942.

67 Ibid., at p. 943.

68 E. Truman, Inflation Targeting in the World Economy, Peterson Institute for International Economics, 2003, Section 3.

69 G. Hufbauer, D.D. Xie, op. cit., at pp. 943-944.

70 Ch. Bummer, Why Soft Law Dominates International Finance - and not Trade, 'Journal of International Economic Law' 2010, vol. 13, no 3, p. 623, at p. 623. 
which heads of states do participate on a regular basis, is the G20, ${ }^{71}$ but still it represents only a minority of the world's states.

The $\mathrm{WTO}^{72}$, the $\mathrm{IMF}^{73}$ and the World Bank ${ }^{74}$ all have obligations to cooperate with international organizations having specialized responsibilities in related fields. Article XV Para. 2 of the General Agreement on Tariffs and Trade (GATT) obliges the WTO to consult with the IMF on issues referring to monetary reserves, balances of payments and foreign exchange arrangements. The IMF may also play an important role when a WTO member tries to invoke Article XII or XVIII, Section B of the GATT to safeguard the balance of payments. The GATT addresses cooperation between the WTO and the IMF several more times. ${ }^{75}$ So does the General Agreement on Trade in Services (GATS).$^{76}$ Articles XXXVI and XXXVIII of the GATT address cooperation between the WTO and the World Bank. Already during the Uruguay Round a Declaration of the World Trade Organization to Achieving Greater Coherence In Global Economic Policymaking ${ }^{77}$ was adopted. The WTO signed cooperation agreements with the IMF and the World Bank as early as 1996 and 1997. They provide for information exchange, consulting, participation in each other's work and staff cooperation. The Bretton Wood Institutions are also supportive to international trade. For example Article VIII Section 2(a), Article VI Section 3 and Article XIV Section 2 of the IMF's Articles of Agreement give the IMF authority with respect to payments.

The loans granted by the IMF and the World Bank have a direct impact on international trade relations. The coexistence of the WTO with the Bretton Woods Institutions has not been challenged during the past decades, which is why there has been so little academic research on the subject. ${ }^{78}$

71 Ibid., at p. 627.

72 Marakesh Ageement, Article III, Para. 5.

73 IMF Articles of Agreement, Article X.

74 IBRD Articles of Agreement, Article V, Section 8.

75 For example Article VII Para. 4(c), Article II, Para. 6(a).

76 Article XI Para. 2, Article XII Para. 2(b) and Article XXVII.

7733 I.L.M. 1125, 1249 (1994).

78 D. Ahn, Linkages between International Financial and Trade Institutions. IMF, World Bank and WTO, 'Journal of World Trade' 2000, vol. 34, no 4, p. 1 at p. 28. 


\subsection{The Domination of Soft-law}

Why is hard-law hard? Because a breach thereof results in a state's international responsibility or liability. Hard-law is enforceable and usually more transparent. Since a breach of hard-law gives rise to consequences, there is a strong incentive to comply with treaties. It also helps governments resist domestic pressure to act in a manner disadvantageous for other states. Soft-law does not have such an effect. It enables a cheap exit from commitments. It is characteristic for power-driven and not rule-oriented organizations. Soft financial law can be divided into three subcategories: ${ }^{79}$ best practices (relating to capital adequacy, disclosure rules, due diligence, money laundering prevention, often in the form of codes of conduct), regulatory reports and observations (data collection, records production) and information-sharing and enforcement cooperation (often in the form of memoranda of understanding). The advantages of soft-law include lowering the costs of contracting and fewer sovereignty costs (greater ability to follow national prerogatives). ${ }^{80} \mathrm{~A}$ breach of soft-law does not entail reputational consequences.

What is typical about international financial law is that it is almost entirely soft law. The most famous example is probably the Basel Accords. ${ }^{81}$ Some experts say that it should remain so. Hard-law is sometimes vague or imprecise, in order to remain flexible. Treaties enable reservations, which result in unequal rights of signatories. On the other hand, coordination that is not binding allows parties to experiment in their domestic markets and introduces regulatory competition. Nongovernmental agencies seem to be more technocratic and less politically influenced than international organizations established by states. Private companies often seek to adopt international agency capital standards or to submit voluntarily to major financial centres in order to build their reputation as credible institutions. ${ }^{82} \mathrm{~A}$ few experts have suggested that,

79 Ch. Bummer, op. cit., at p. 629.

80 Ibid., at p. 631.

81 Recommendations on banking regulations issued by the Basel Committee on Banking Supervision (so called Basel I, Basel II and Basel III).

82 See Ch. Brummer, op. cit., at pp. 633-639. 
even though international financial law is technically not-binding, it is in fact hard law. ${ }^{83}$ The author of this article does not share this view.

Since international financial law is soft-law, financial hard-law is dominated by domestic regulations. As a result there is a paradoxical situation, whereby financial law is amongst the most regulated businesses in domestic law, yet amongst the most unregulated in international law. ${ }^{84}$ The crisis revealed an obviously insufficient coordination of states in financial supervision and exposed the devastating effects of the absence of any international financial supervisory authority. For this reason, the author of this article argues that international financial hard-law is the only cure for global financial crises.

As mentioned earlier, the primary focus of international financial law is stabilization. But this remark refers only to governments. Private actors on the other hand have pressured for the liberalization of financial services, to expand to other states (continents) and to increase their profits (notably Goldman Sachs, Citibank, Deutsche Bank, AIG, GE Capital). ${ }^{85}$ This is another important factor, explaining why there is so little international hard-law on this subject.

\section{Who Should Be Responsible for International Financial Supervision?}

As mentioned above, the supervision over international financial markets requires controlling governments and ensuring that they in turn control private actors. The monitoring of international government failures exists in some areas: the ILO Constitution promotes the human conditions of labour in international relations, the IMF promotes exchange stability and the WTO prevents protectionism. ${ }^{86}$ No institution, however, oversees financial failures.

There are two possible solutions to this problem. One is to adopt a formal and binding international agreement governing the financial

83 Ibid., at p. 623.

84 T. Cottier, Challenges Ahead in International Economic Law, 'Journal of International Economic Law' 2009, vol. 12, no 1, p. 3, at pp. 7-8.

85 G. Hufbauer, E. Wada, op. cit., at p. 572.

86 S. Charnovitz, op. cit., at p. 745. 
discipline of its signatories. The other is to grant the authority to supervise the financial affairs of states to an existing international organization or to create a new one for that purpose. An international agreement, in order to fulfil its obligations, would have to establish international bodies, supervising the observance of law by states. In that regard, it would resemble an international organization. In both cases, states may adopt one of two models: symmetric (equal decision rights for all participants) or asymmetric (division into leading and subordinated states) ${ }^{87}$ Regardless of the specific solution, a credible financial system requires consensus on goals and procedure. ${ }^{88}$

The financier George Soros called for the establishment of a publicly funded international credit insurance corporation. ${ }^{89}$ Currently the establishment of an international financial supervisory authority seems to be rather utopian. ${ }^{90}$ But isn't it more reasonable not to create a new organization and, as an alternative, to extend the mandate of an existing one instead? It would definitely keep the costs low(er). And isn't it more reasonable to provide emergency loans instead of compensation through insurance? It would minimize the moral hazard. Costs and moral hazard are among the most significant difficulties of international financial stability.

Further in this article, the existing international economic institutions shall be examined, in order to determine which is the most capable of fulfilling the task of international financial supervision.

\subsection{The IMF}

\section{1.l. The Birth and Evolution of the IMF}

Before World War II, states held their monetary reserves in gold, silver and foreign currencies and no international regime regulating these issues was in place. The Bretton Woods Conference took place in July 1944 in New Hampshire, US. The purpose was to preserve peace through ensuring economic stability. Newly established international organizations were to be charged with this task. The prevention of hyperinflation,

87 E. Baltensperger, T. Cottier, op. cit., at p. 921.

88 Ibid., at p. 923.

89 See G. Soros, The Crisis of Global Capitalism, Boston, Little Brown, 1998.

90 Ch. Tietje, M. Lehmann, op. cit., at p. 671. 
unemployment and fluctuations of exchange rates was the main intention of the architects of the post-war international economic infrastructure (John Maynard Keynes of the UK and Harry Dexter White of the US). ${ }^{91}$ The International Monetary Fund (IMF) and the International Bank for Research and Development (IBRD) were supposed to be complemented by the International Trade Organization (ITO), but the rejection of the latter by the US Congress resulted in the establishment of the GATT, which transformed into the World Trade Organization (WTO) half a century later. Apparently, not all aspects of Keynes' and White's plan were realized.

Since the UK was likely to be a debtor, Keynes insisted that members be permitted to draw at will from the Fund. The US was about to be a creditor, which explains why White wanted lending to be conditional upon internal reforms. Originally, this issue was left unsettled, but eventually the American position prevailed. ${ }^{92}$ What must be considered a success of both arguments is the abandonment of the idea of harsh repatriations towards Germany, which had already failed once and contributed to the rise of National Socialism after World War I. ${ }^{93}$

Since the establishment of the IMF, exchange rates have been fixed and tied to the US dollar. In 1973 the flexible exchange rates system prevailed and has dominated the global economy ever since. Automatic adjustments were supposed to solve the problem of international financial imbalances, but they did not prevent occasional, but sometimes severe, financial crises. ${ }^{94}$

Recently the IMF shifted its attention from strictly macroeconomic policies to private finance. ${ }^{95}$ Liberalized capital flows can be beneficial, since they provide low-cost capital to emerging markets, accompanied by the transfer of technology and know-how. However, at the same time, unregulated capital flows may cause a dangerous expansion of credit and inflationary pressures and deteriorate an account balance. The IMF already considered amending the Agreement to adopt the role of an international

91 R.M. Lastra, The International Monetary Fund in Historical Perspective, 'Journal of International Economic Law' 2008, vol. 3, no 3, p. 507, at p. 508.

92 A.F. Lowenfeld, The International Monetary System: A Look Back over Seven Decades, 'Journal of International Economic Law' 2010, vol. 13, no 3, p. 575, at p. 579.

93 R.M. Lastra, The International Monetary Fund..., at p. 508.

94 E. Baltensperger, T. Cottier, op. cit., at p. 919.

95 G. Hufbauer, E. Wada, op. cit., at p. 572. 
capital movements supervisor in $1997 .{ }^{96}$ The global financial crisis of 2007-2009 drew public attention again to this problem. Many Asian and European states liberalized their restrictions on capital movements prematurely. Investor protection proceeded financial stability. Even without amending the Agreement, the IMF could, pursuant to Article IV, Section 1, establish policies to determine when a member should, and when it should not, liberalize its capital account. However, even if the IMF's experts predict a crisis, there is nothing they can do to force the failing economy to adopt new policies, unless the government requests assistance.

\subsubsection{The Functioning of the IMF}

The purpose of the IMF is to monitor its members' economies, give them advice and lend money (subject to interest) in the event of a crisis. The Fund's resources come from mandatory contributions from its members, paid quarterly in gold, SDRs ${ }^{97}$ or their own currencies. ${ }^{98}$ Technically the IMF does not lend money. The borrower actually purchases reserve assets from the IMF. ${ }^{99}$ Currently, the IMF's mandate is obviously not broad enough to supervise international finance in general. What is more disturbing is that its effectiveness in fulfilling its traditional tasks has even been called into question. Some have noted that, on the one hand, emerging economies prefer to accumulate reserves on their own and that, on the other hand, large members refuse to follow the organization's advice. This is due to a lack of confidence in the IMF's capacity. This is referred to as the effectiveness deficit, which in turn causes a legitimacy deficit. ${ }^{100}$

96 Official website of the IMF, http://www.imf.org/external/np/cm/1997/cm970921. htm [last accessed on 30.11.2013].

97 Special Drawing Rights, regulated in Article XV of the IMF Articles of Agreement. See footnote 117.

98 Article III Section 3 of the IMF Articles of Agreement.

99 H.R. Torres, Reforming the International Monetary Fund - why its Legitimacy is at Stake, 'Journal of International Economic Law' 2007, vol. 10, no 3, p. 443, at p. 443.

100 H.R. Torres, op. cit., at p. 444. See also D.B. Bradlow, Rapidly Changing Functions and Slowly Evolving Structures: The Troubling Case of the IMF, 'American Society of International Law Proceeding' 2000, vol. 94, April 5-8, at p. 152; H. Dieter, The Decline of the IMF: Is It Revesible? Should It Be Reversed?, 'Global Governance' 2006, vol. 12, at 
The structure of the IMF consists of three main bodies: 1 . the Board of Governors, 2. the Executive Board, 3. the Managing Director. ${ }^{101}$ The structure of the International Bank for Research and Development is analogous, with one exception - there is a President instead of the Managing Director. ${ }^{102}$ The Boards of Governors consist of finance ministers or central bank governors, who gather on a regular basis. The Executive Board, on the other hand, sits continuously. Traditionally, the President of the Bank has always been an American and the President of the IMF a European (five of the eleven Directors to date have been French). ${ }^{103}$

The powers of the IMF may be divided into three categories: a) regulatory, b) financial and c) advisory. ${ }^{104}$ Its regulatory powers include bilateral surveillance, based on Article IV, Section 1 and Article IV, Section 3(b). Actions required from members, in order to cooperate with the IMF, include not only external policies, but also domestic policies, since they influence one another and one member's financial instability may result in international instability. Multilateral surveillance is regulated in Article IV, Section 3(a). Finally, according to Article VIII, the IMF has jurisdiction over current international payments and transfers. According to Article VIII, Section 5, members are required to provide information to the IMF when requested. Financial powers are exercised by lending money to the members undergoing a crisis on a conditional basis (Article V, Section 3). Advisory powers include performing, upon request, financial services and technical services (Article V, Section 2(b)). They are voluntary on both sides (for the member and for the IMF).

p. 343; D. Dodge, J. Murray, The Evolving International Monetary Order and the Need for an Evolving IMF, 'Global Governance' 2006, vol. 12, at p. 361; J.M. Griesgraber, O. Ugarteche, The IMF Today and Tomorrow: Some Civil Society Perspectives, 'Global Governance' 2006, vol. 12, at p. 351; P.R. Masson, The IMF. Victims of its own success or institutional failure?, 'International Journal' 2006-2007, vol. 62, no 4, at p. 889; W.A. Niskanen, Reshaping the Global Financial Architecture: Is There a Role for the IMF?, 'Cato Journal' 1999, vol. 18, no 3, at p. 331; J. Shelton, The IMF and Its barbarous Relic, 'Cato Journal' 2010, vol. 30, no 3, at p. 505; C. Tan, Reform or Reinvent? The IMF at a Crossroads, 'Global Governance' 2006, vol. 12, at p. 507.

101 Article XII, Section 1 of the IMF Articles of Agreement.

102 Article V, Section 1 of the IBRD Articles of Agreement.

103 The official website of the IMF http://www.imf.org/external/np/exr/chron/mds.asp [last accessed on 30.11.2013].

104 R.M. Lastra, The International Monetary Fund..., at p. 515 ff. 
Financial assistance for states experiencing balance of payments problems (spending more money than they take in) is conditional upon the borrower adopting particular monetary, exchange rates and fiscal policies. This was not always the case and the Articles of Agreement are silent on this matter. The rationale of this concept is that balance of payment problems are the consequence of failures in the member's economy. Therefore simply lending it money will not solve the problem, because the state will still spend more than it earns. ${ }^{105}$

The Fund exercises its surveillance through consultations and publications. It all starts with the annual meeting, visits in member states to collect information and discussions with authorities. The conclusions are published only with the consent of the interested member. As mentioned above, the focus is not only on exchange arrangements, but also on good governance, bank restructuring etc. ${ }^{106}$ As mentioned above, surveillance is regulated in Article IV, Section 3. Point (a) provides that the Fund shall oversee the international monetary system in order to ensure its effective operation, and shall oversee the compliance of each member with its obligations. Point (b) provides that each member shall provide the Fund with the information necessary for such surveillance and, when requested by the Fund, shall consult it. Members are often reluctant to answer the Fund's inquiries. ${ }^{107}$ In general, the IMF's surveillance is dependent upon the quality of information provided to it by its members. Additionally, states are not required to disclose information about individuals or corporations. ${ }^{108}$

Learning from the Mexican crisis of 1995 and the Asian crisis (Thailand, Indonesia and South Korea) of 1997 the IMF already took on the role of the lender of last resort. For this reason, some experts suggest that, in order to be able to fully fulfil this task, the IMF should hire a new team of experts in law, banking and finance, which it currently lacks. ${ }^{109}$ By doing so, it could develop a ranking system for states' banking and financial systems. The IMF would extend its surveillance beyond macro-

105 Ibid., at p. 516.

106 Ibid., at pp. 512-515.

107 A.F. Lowenfeld, op. cit., at p. 585.

108 Articles of Agreement, Article VIII, Section 5(b).

109 R.M. Lastra, The International Monetary Fund..., at pp. 521-522. 
economic policies to micro-economic (prudential financial supervision). ${ }^{110}$ The Fund also already runs the Financial Sector Assessment Program (FSAP), which produces periodic detailed analyses of individual members' financial systems. The program was initiated following the Asian crisis. Its weakness is its voluntary nature, which assigns it to the advisory, as opposed to the regulatory, power of the IMF.111 Other IMF initiatives should also be appreciated, namely the Global Financial Stability Report ${ }^{112}$ and the World Economic Outlook ${ }^{113}$.

The recent crisis reminded states that the IMF is still needed, which was manifested through the large increase in the number of members who received financial support. The IMF improved the flexibility and effectiveness of assistance and also tries to gather more resources for the future. ${ }^{114}$

\subsubsection{The Pros of IMF as International Financial Supervisor.}

The IMF seems to be a natural candidate to act as an international financial supervisor. It already has extensive experience in designing early warnings indicators. ${ }^{115}$ What is also very important is that the IMF has already proved that it is able to adapt to changes in economic circumstances and to accept new missions. It is worth remembering that, originally, the IMF was responsible only for supervising the par value regime in terms of gold or the US dollar. ${ }^{116}$ In 1969, a new sui generis virtual currency - Special Drawing Rights (SDR) - was introduced. ${ }^{117}$ This

110 Ibid.

111 S. Hagan, op. cit., at p. 961.

112 The official website of the IMF, http://www.imf.org/external/pubs/ft/gfsr/index. htm [last accessed on 30.11.2013].

113 The official website of the IMF, http://www.imf.org/external/pubs/ft/weo/2012/02/ index.htm [last accessed on 30.11.2013].

114 S. Hagan, op. cit., at p. 955.

115 G. Hufbauer, D.D. Xie, op. cit., at p. 952.

116 Par value regime required that exchange transactions within a state's territory do not differ from parity by more than $1 \%$ in either direction. It was provided in the Article IV Section 3 of the Articles of Agreement, but is no longer in force.

117 Technically it is not a currency, but foreign exchange reserve assets, defined by the US dollar, the euro, the British pound, and the Japanese yen. It is still used in circulation for example in the United Nations Convention on the Contract for the International Carriage of Goods by Road (CMR Convention) - Article 23 Para. 7-9 or 
was the first amendment to the Articles of Agreement of the IMF. In 1967, the UK was no longer able to resist pressure on the British pound and announced a devaluation. The US President Johnson confirmed the commitment of the US to convert dollars to gold on a fixed rate. But in 1971, six years into the Vietnam war, US reserves dropped to 10 billion dollars and the Japanese economy grew enormously, following which the US President Nixon withdrew this declaration. By 1973 all major currencies were floating, even though members were allowed to choose whether they want to keep the par value regime or switch to the flexible one. This led to the second amendment of the IMF law in 1978. The title of Article IV "Par Value of Currencies" was changed to "Obligations Regarding Exchange Arrangement"; however in fact it did not contain any obligations, except for avoiding the manipulation of exchange rates. ${ }^{118}$ From that time, members had 3 options of how to maintain the value of their currency: 1 . in terms of another currency or the SDR, 2. in cooperative arrangements with other members, 3. using any other exchange arrangements of the member's choice. States with flexible exchange rates have independent monetary policies, but are strongly affected by international markets. States with fixed exchange rates have price stability, but private capital flows may force them into costly devaluations. States with intermediate regime (pegged or managed exchange rate) tend to crumble easily under speculative attacks. ${ }^{119}$ In such economies, private investors tend to assume exchange rate stability and take excessive exchange rate risks, thereby contributing to the threat of market breakdown. The same may happen when a state declares fixed rates but fails to back this up with hard monetary policies. ${ }^{120}$

Such a significant change could have called the very rationale of the IMF into question. But, surprisingly, this change quickly ceased to be viewed as a catastrophe. It is true that the IMF did not have a major role in the international economic system and that the GATT became the leading legislation of the international economy. But the IMF survived

in the International Maritime Organization Convention on Limitation of Liability for Maritime Claims - Article 8.

118 A.F. Lowenfeld, op. cit., at p. 583.

119 S.D. Sharma, op. cit., at pp. 68-69.

120 G. Hufbauer, E. Wada, op. cit., at p. 591. 
and it proved useful in debt restructuring of the least-developed countries in the 1980s and in the transition of communist states into market economies in the 1990s. ${ }^{121}$ The IMF did not engage in sponsoring longterm infrastructure projects, since this was the role of the World Bank, but it assisted states with loans. At the dusk of colonialism, former colonies joined the IMF and they could afford very low quotas, while their needs were huge.

According to Article V Section 3, members could draw up to $200 \%$ of their quotas, but Article V Section 4 provides that, in a crisis situation, the Fund could waive this limit and, in fact, the Fund regularly granted up to 4000 times state quotas. ${ }^{122}$ Almost all borrowers were developing and emerging markets, and they treated the IMF as a lender of last resort. As long as they could, they borrowed money from private institutions, because the latter did not make lending conditional upon the adoption of any special economic policies. When a crisis got out of control, they turned to the IMF. ${ }^{123}$ The IMF also played a major role in financial assistance for some of the most heavily populated states in the world, including Mexico (1982-1983 and 1994), Brazil (1982-1983 and 1998-1999), South Korea, Philippines, Thailand, Indonesia (19971998), Russia (1996-1999) and Argentina (2000-2007). ${ }^{124}$ But what is significant here is that, while so doing, the IMF evolved, step by step, from a strictly international monetary institution into an international economic institution, monitoring members' payment systems, banking and capital markets and financial policies. That was possible without any major reforms of the organization, given the broadly enumerated goals in Article I of the IMF's Articles of Agreement. ${ }^{125}$

\subsubsection{The Cons of IMF as International Financial Supervisor}

The goals of the IMF are broad, yet they are limited. Its limited mandate remains its weakness. Another weakness is its voting mechanism. ${ }^{126}$

121 R.M. Lastra, The International Monetary Fund..., at p. 507.

122 A.F. Lowenfeld, op. cit., at p. 586.

123 Ibid., at p. 587.

124 For details see A.F. Lowenfeld, op. cit., at pp. 587-595.

125 R.M. Lastra, The International Monetary Fund..., at pp. 512-514.

126 Ch. Tietje, M. Lehmann, op. cit., p. 675. 
The IMF Articles of Agreement already forbid the manipulation of exchange rates with the purpose of preventing balance of payments issues. ${ }^{127}$ The problem is that the provisions of IMF law do not placed any specific obligations on its members, such as engaging in consultations, negotiations and dispute settlement. ${ }^{128}$ Therefore, proving that a member violated Article XXVI Section 2 of the Articles of Agreement is highly unlikely. The system in which states are accountable to the IMF for their financial discipline, including strict supervision over private actors, goes even further beyond the current scope. For the foregoing reasons, the IMF is not reckoned with except for during times of crisis. Its early warnings could simply be disregarded.

Returning to the voting mechanism, one should bear in mind that the participation of states in decision-making is directly dependent upon their making financial contributions to the organization's budget. In other words: members buy their votes and rights. Unlike the WTO (or the United Nations), the IMF (along with the World Bank) is driven by real power of the economically strongest members and not by any formal power of all equal members. ${ }^{129}$ Even though there is no veto, powerful actors such as the US or the EU can individually block any major decision. ${ }^{130}$ What is also criticized is that the EU is not itself a member of the IMF, therefore the member states of the EU have separate Directors in the IMF. The result is that the EU has multiple Directors whereas the US has only one. ${ }^{131}$ According to the calculations of Hector Torres, as of 2007, 28 countries with advanced economies, representing $14 \%$ of the world's population, held $61 \%$ of the voting power both at the IMF and the World Bank. ${ }^{132}$ States cannot contribute as much as they like, but the exact contribution amount is calculated by using very complicated formulas, which give absurd results. For example, until recently, Switzerland had a higher tariff than Brazil, Belgium and India. ${ }^{133}$ This situation partially changed with the adoption of the Resolution on Quota and Voice reform

127 Article IV Section 1(iii) of the IMF Articles of Agreement.

128 E. Baltensperger, T. Cottier, op. cit., at p. 935.

129 H.R. Torres, op. cit., at p. 445.

130 A.F. Lowenfeld, op. cit., at p. 577.

131 Ibid.

132 H.R. Torres, op. cit., at p. 445.

133 Ibid., at p. 447. 
at the International Monetary Fund's $61^{\text {st }}$ Annual Meeting in Singapore in $2008{ }^{134}$ It is worth mentioning that states' access to the IMF's resources also relies on their contributions. As a consequence, the developing states, which usually need assistance the most, cannot draw much on a regular basis, but borrow money beyond their annual limit and therefore with greater costs. ${ }^{135}$ Ultimately, the costs of the functioning of the IMF (where salaries are annually indexed and benefits are first class) are borne by the developing countries taxpayers. ${ }^{136}$ The contribution of the borrowers to the IMF's budget rose from $29 \%$ in 1980 to $71 \%$ in $2000 .{ }^{137}$ With this in mind, one may consider the current voting system to be dysfunctional.

Another controversy is tying the conditionality of financial assistance from the IMF, which undermines confidence in democracy (the IMF decides about the distribution of the financial help). ${ }^{138} \mathrm{~A}$ state in need sends a Letter of Intent to the Fund, signed by the Minister of Finance of the Central Bank Governor, which presents proposed policies. Such letters are usually not discussed within national parliaments. Even though breaching policies presented in the Letter does not constitute a breach of international law and does not give rise to the penalties provided for in Articles XXVI Section 2(a-c) of the Articles of Agreement, it may effectively preclude a state from drawing more money from the Fund in the future. ${ }^{139}$ In order to make the borrowing process more flexible, during the consideration of the Letter, the state may borrow unconditionally a smaller amount of money by using stand-by arrangements. ${ }^{140}$

Furthermore, the financial capacity of the IMF to fulfil the task is questionable. The IMF's incomes come from interests on loans. During times of economic prosperity, when states do not need loans, the IMF generates a deficit. Such a situation took place for example in 2007, when

134 The official website of the IMF, http://www.imf.org/external/np/exr/facts/quotas. htm [last accessed on 30.11.2013].

135 H.R. Torres, op. cit., at p. 450.

136 Ibid., at p. 452.

137 N. Woods, D. Lombardi, Uneven patterns of governance: how developing countries are represented in the IMF, 'Review of International Political Economy', 2006, vol. 13, no 3, p. 480 , p. 498.

138 H.R. Torres, op. cit., at p. 448.

139 A.F. Lowenfeld, op. cit., at p. 580.

140 Ibid. 
the organization's balance was $-17 \%$ and dropping. It was the crisis of 2007-2009 that saved the IMF from the danger of insolvency. ${ }^{141}$

The public cost of banking panic is so huge that governments establish central banks with the role of lender-of-last-resort. An analogous institution is desirable at the international level. But the resources of the IMF are very small compared to private global capital flows. Furthermore, the IMF is unable to react freely (it cannot issue currencies) nor quickly (it requires members' approval and borrowing agreement). Obviously the IMF, when acting, must distinguish between non-liquid and insolvent states, so that it assists temporarily non-liquid but solvent states (with loans containing penalty rates, when private actors are unwilling to lend). ${ }^{142}$

The IMF possesses institutional resources, administrative capacity, worldwide membership, broad experience and technical competence to coordinate global crisis management. ${ }^{143}$ It could be not only the lenderof-last-resort but also the international financial supervisor. However, the IMF is not ready to take on new assignments without strengthening and broadening its mandate. Other obstacles include its voting mechanism, democratic deficit and limited resources. Some changes may be possible under the existing Articles of Agreement, whereas others may require the amendment thereof.

\subsection{The WTO}

\subsubsection{The Birth and Evolution of the GATT/WTO}

The WTO is not a traditional Bretton Woods institution. Its predecessor, the GATT, was simply a treaty which eventually was used to replace the International Trade Organization, which in turn never really came to exist. While the Bretton Woods institutions dealt with states' macro-economic policies to sustain stability in the international financial system, the GATT's focus was on sector-specific trade policies. ${ }^{144}$

Since their establishment, the IMF and the World Bank have been provided with a considerable staff. The GATT struggled with insufficient

141 H.R. Torres, op. cit., at p. 451.

142 S.D. Sharma, op. cit., at p. 60.

143 Ibid., at p. 51.

144 D. Ahn, op. cit., at p. 6. 
human resources at least until 1968, when the US Congress granted permanent contributions to the organization. In the 1970s, when financial international relations were sharply modified by the freeing of exchange rates, the trade world made great progress by concluding the most ambitious round of negotiations thus far - the Tokyo Round. ${ }^{145}$ Between 1980-1995, the economy was repeatedly tormented by financial crises. The international community, with the USA and the IMF taking the lead, effectively handled the recovery. But the international financial system remained fragmented, complex, multi-dimensional and resourceoriented. At the same time, in the trade world the community came to the conclusion that it's time to introduce even harder law - a rule-based system with juridical function in a single undertaking. So the World Trade Organization was established. ${ }^{146}$

The GATT began as the little brother of the IMF and the World Bank. It seems, though, that the WTO is now the tent-pole holding up the international economic system, in which the two other pillars are showing signs of distress. ${ }^{147}$ The objective of the world trading system was the liberalization of commerce, and of the world financial system - the stabilization of markets. ${ }^{148}$ Over the last decades, the former has functioned well, whereas the latter has failed on multiple occasions.

\subsubsection{The Functioning of the WTO}

In contrast to the Great Depression of 1930s, the global financial crisis of 2007-2009 did not result in states adopting extensive protectionist measures. This fact significantly softened the repercussions of the crisis and the WTO takes the credit for this. ${ }^{149}$ That is not to say that everything went smoothly. One thing to remember is that the US adopted the American Recovery and Reinvestment Act, which prohibited state and local governments from receiving federal aid for public works (an unprecedented 787 billion dollars), unless the goods used for those works were manufactured in the USA. This situation exposed how little other

R. M. Gadbaw, op. cit., at p. 559.

Ibid., at p. 562.

47 Ibid., at p. 572.

148 G. Hufbauer, E. Wada, op. cit., at p. 567.

149 E. Baltensperger, T. Cottier, op. cit., at p. 926. 
states may rely on the USA during times of crisis, ${ }^{150}$ not to mention that some experts claimed that it was illegal under the WTO regulations. ${ }^{151}$

The juridical and rule enforcement side of the WTO seems to work very well. However, rule making and legislation malfunction. In the times of GATT, eight rounds of negotiations were conducted. In the WTO none. The organization is unable to reform. If this situation continues, the WTO will shortly be obsolete, which may encourage its members to turn to regional economic organizations. It will become inefficient in the face of modern challenges, just as financial law did.

Obviously, the Bretton Woods institutions do influence trade.

Article I of the IMF's Articles of Agreement sets facilitating of the expansion and balanced growth of international trade as one of the purposes of this organization. So does Article I of the IMRD Articles of Agreement. In practice, for example, exchange rates affect the calculation of dumping margins and subsidy impact.

The predictable, transparent, reliable and rule-based trading system of the WTO may transpire to be insufficient to keep international trade running when unforeseen changes in exchange rates completely alter the conditions for competition. The global economy can function well only when both branches of international economic law are properly designed and enforced. Does that imply that the WTO should be responsible for supervision over both branches?

\subsubsection{The Pros of the WTO as International Financial Supervisor}

The WTO's law is shaped in a completely different way than the law of the IMF. It is namely designed to regulate relations between member states. The WTO does not intervene to support states in crisis, nor does it promote specific trade policies. The IMF's law, on the other hand, regulates relations between the organization and its members, so the IMF plays an active role during times of financial crises. ${ }^{152}$

150 S. Charnovitz, op. cit., at p. 752.

151 J. Bhagwati, Defending an Open World Economy, [in:] T.L. Anderson, R. Sousa (eds.), 'Reacting to the Spending Spree: Policy Changes We can Afford', Hoover Institution Press, Stanford 2009, at pp. 141-144.

152 E. Baltensperger, T. Cottier, op. cit., at p. 933. 
A. Charnovitz explains, the WTO is focused on fighting government failure and not market failure. This is why it deals with subsidies, tariffs and non-tariff barriers, but not with labour markets, antitrust law, environmental protection or financial markets. ${ }^{153}$ The attractiveness of the WTO is that it provides hard law and the accountability of governments, given its effective dispute settlement mechanisms.

As a consequence of the great crisis, which began after the fall in stock prices in the USA in September 1929, the US Congress passed in 1930 the Smoot-Haley Tariff Act, which erected enormous tariff barriers on imported goods. As mentioned above, it effectively reduced both the value and the volume of international trade with the US by $50 \%{ }^{154}$ In contrast, the 2007-2009 crisis resulted in almost no decline in international trade caused by government intervention. ${ }^{155}$ On the contrary, international trade is perceived as one of the factors which helped to limit the effect of financial breakdown. ${ }^{156}$

Among the reasons why the WTO performed so well, various experts offer the following ${ }^{157}: 1$. a rule-oriented approach which guarantees predictability and stability, 2. rules serving the overall public interest (reciprocity, the ability to start a case when benefits are nullified or impaired), 3. an efficient dispute settlement system and enforcement, 4. hard law which prevents governments from yielding to domestic pressure for protectionism, 5. its universal character (153 members comprising over $90 \%$ of world trade and $90 \%$ of the world's population; covering virtually any measure regulating trade and including non-violation complaints), 6. transparency (mandatory disclosure of information), and 7. consensus-based decision making (even though it hinders amending WTO law), which collectively provide great legitimacy.

The WTO already regulates trade in financial services included in the GATS, the Annex on Financial Services attached to the GATS, and the

153 S. Charnovitz, op. cit., at p. 754.

154 R. M. Gadbaw, op. cit., at p. 554.

155 See B. Ruddy, The Critical Success of the WTO: Trade Policies of the Current Economic Crisis, 'Journal of International Economic Law' 2010, vol. 13, no 2, p. 475.

156 See S.J. Evenett, B.M. Hoekman, O. Cattaneo (eds.), Effective Crisis Response and Openness: Implications for the Trading System, Washington DC: World Bank and Center for Economic and Policy Research 2009, at p. 5.

157 See R. M. Gadbaw, op. cit., at pp. 568-572. 
Understanding on Commitments in Financial Services, which is optional. ${ }^{158}$ The GATS is lex generalis, whereas the latter two are lex specialis. ${ }^{159}$ The GATS applies to all kinds of services, but the opening of markets also depends on specific commitments of states in which limitations to market access and national treatment are present. ${ }^{160}$ (see art. XVI, XVII, XX).

The core commitments in the GATS are: 1) most-favoured-nation treatment (Article II), national treatment (Article XVII), market access (Article XVI) and transparency (Article III). ${ }^{161}$ Unlike goods, many aspects of trade in services are flexible, discretionary and non-quantifiable. ${ }^{162}$ But unlike the Basel Committee and the IOSCO, the GATS does not set substantive regulatory standards. It merely creates a framework for national regulatory regimes. ${ }^{163}$ WTO members retain the right to pursue national policy objectives (arts. XIV, II, XVII and VI).

\subsubsection{The Cons of WTO as International Financial Supervisor}

The prohibition on export subsidies, regulated in the WTO Agreement on Subsidies and Countervailing Measures (SCM), worked well during the recent crisis, but the prohibition on import-substitutions subsidies (countervailing duties) and especially domestic subsidies did not prove to be as successful. ${ }^{164}$ As regards export subsidies, the complaining member need not prove any adverse effects. Since SCM covers trade in goods and not in services, certain experts estimate that approximately $\$ 9.8$ trillion of the $\$ 12$ trillion in federal crisis relief in the USA was provided to services. ${ }^{165}$ This is merely an example of the weaknesses in the functioning of the WTO.

158 E.H. Leroux, Trade in Financial Services under the World Trade Organization, 'Journal of World Trade' 2002, vol. 36, no 3, p. 413, at p. 414.

159 R. Bismuth, op. cit., at p. 493.

160 Ibid., at p. 494.

161 M. Bagheri, Ch. Nakajima, op. cit., at p. 516.

162 J. Cooke, The Emergence of Domestic Regulation as a Focal Issue in the GATS 2000 Service Negotiations, 'International Trade and Regulation' 2000, vol. 6, no 5, p. 141, at p. 142.

163 M. Bagheri, Ch. Nakajima, op. cit., at p. 524.

164 G.N. Horlick, P.A. Clarke, WTO Subsidies Discipline during and after the Crisis, 'Journal of International Economic Law' 2010, vol. 13, no 3, p. 859, at p. $859 \mathrm{ff}$.

165 G. Hufbauer, L. Rubini, Y. Wong, Swamped by Subsidies: Averting a US-EU Trade Was after the Great Crisis, Policy Note, 24.7.2009. 
The GATS, similarly to other trade agreements, does not regulate micro prudential rules. Furthermore, the Financial Services Annex excludes the activities of central banks, social security systems and governmental financial resources from the scope of the GATS. ${ }^{166}$

The WTO law supervisory model is based on mutual monitoring by member states. This structure may not necessarily fit financial relations because, unlike trade relations, the risk exists in financial relations that governments create requirements that are too soft on private actors, rather than being too harsh. The purpose is different (stability instead of liberalization) and therefore the mechanisms must also be different.

But the most important problem is that the WTO's expertise in finance is insufficient for it to assume the supervisory task. As mentioned above, whenever it requires assistance in this regard, it turns to the IMF. Of course, its resources can be reinforced. However, it seems more reasonable to adjust a financial organization to fulfil supervisory obligations over finances rather than fundamentally change a trade organization.

\subsection{Other Candidates}

\subsubsection{The World Bank}

The International Bank for Reconstruction and Development (IBRD) is the original branch of the World Bank, created at the Bretton Woods Conference in 1944. It specializes in near-market-rate lending (hard lending) to mostly middle-income countries. The International Development Association (IDA) is the concessional lending arm of the Bank. Established in 1960, it provides grants and interest-free loans (soft lending) to the poorest countries. ${ }^{167}$ The World Bank and IMF lending are complementary: when a country participates in an IMF program, it receives more World Bank lending. ${ }^{168}$ It creates a valuable alternative financing stream during periods of financial stress.

166 P. Delimatsis, P. Sauve, op. cit., at p. 848.

167 M.S. Winters, The World Bank and the Global Financial Crisis: The Reemergence of Lending to Middle-Income Countires, 'Whitehead Journal of Diplomacy and International Relations' 2011, vol. 12, no 2, p. 57, at p. 59.

168 Ibid., at p. 62. 
The World Bank also includes the International Finance Corporation, created in 1956. It provides liquidity support to businesses. But IFC lending grew little during the crisis period, therefore its role is not significant in fighting crises. ${ }^{169}$

Prior to the collapse of the Lehman Brothers, the world already dealt with twin minor economic crises in 2008 - the food and fuel prices crises. In July 2008 , the price of oil reached $\$ 126$ per barrel, meaning that the price had more than doubled in a one year. ${ }^{170}$ It must be noted, that the World Bank contributed to fighting the financial crisis. It responded by significantly increasing lending, mostly to middle-income countries, which some experts consider to be the most appropriate behaviour under the circumstances, since those countries were more vulnerable than poor countries to the potential fallout from the financial crisis. ${ }^{171}$ This financing contributed to economic stability in these countries. Importantly, the World Bank will receive financial benefits from such loans over the next two decades and those benefits will be passed along to the poorer countries from the IDA.

Even though the World Bank is a Bretton Woods institution, it is not even taken into account by experts as a potential candidate for international financial supervisor. The reason is that it does not fit the mission in any dimension. It has been established to assist the economic development of states by lending them money. Its borrowers are developing and the least-developed countries. ${ }^{172}$ But as experience shows, world financial crises occur when there is financial turmoil in the most developed economies. Both great crises (in the 1930s and during 2007-2009) were initiated by market collapses in the US. The World Bank neither monitors nor supports rich countries. It may however, as mentioned above, play an important role in fighting crises by providing an alternative stream of funding to states in need.

169 Ibid., at p. 64.

170 Ibid., at p. 57.

171 Ibid., at p. 58 and 63.

172 See D.D. Driscoll, The IMF and the World Bank. How Do They Differ?, available at http://www.imf.org/external/pubs/ft/exrp/differ/differ.htm [last accessed on 30.11.2013]. 


\subsubsection{The G8 and G20}

The G8 is an economic forum which originated with a 1975 summit hosted by France and attended by representatives of six governments (G6 at that time). Currently, it brings together representatives of eight governments: France, Germany, Italy, Japan, the United Kingdom, the United States, Canada and Russia. They discuss problems facing the global economy, such as food and energy shortages. Its relevance is declining and its members are no longer the world's largest economies, since China has surpassed all of them except for the United States, and India and Brazil have already surpassed some of them. The G8 is not an international organization - it has no staff, no budget and no particular legal instruments to influence other states' policies. For these reasons alone it cannot be considered to be a candidate for an international supervisor of any kind.

The decline of the G8 has been accompanied by the rise of the G20. This group was formally initiated in 1999 and its summits are attended by the members' ministers of finance and central bank governors, but also by heads of states or heads of governments. Its mandate is more specific than that of the G8 - the G20 is focused on international financial stability. It is a very politically influential forum but, as with the G8, it is not an international organization.

In June 2010 both groups (G8 and G20) issued declarations (the Muskoka Declaration ${ }^{173}$ and the Toronto Summit Declaration ${ }^{174}$ respectively), expressing their will to strengthen the international financial system. Neither of them contains any relevant substantive provision on their commitments, in particular regarding state responsibility and liability for trans-boundary financial pollution and on the creation of new laws. ${ }^{175}$

173 Available at http://www.whitehouse.gov/sites/default/files/g8_muskoka_ declaration.pdf [last accessed on 30.11.2013].

174 Available at http://www.g8.utoronto.ca/g20/2010/to-communique.html [last accessed on 30.11.2013].

175 S. Charnovitz, op. cit., at p. 757. 


\subsubsection{The Financial Stability Board}

A Similar, but more institutionalized, body is the Financial Stability Board. It was first established as the International Stability Forum in 1999, following the Asian financial crisis of 1997. It was composed of finance ministers, central bank governors and domestic supervisory authorities of the G7 and some other states (Netherlands, Australia, China). Its mandate was to facilitate discussion and co-operation on the supervision and surveillance of financial institutions, transactions and events. After the crisis of 2007-2009, the Financial Stability Forum was replaced in April 2009 in London by the Financial Stability Board. Compared to its predecessor, both its member numbers and its mandate have been extended. It now includes all G-20 countries, which still hardly makes it universal. But the dominant strategy remained soft-law oriented, therefore the institution continues to be more power-driven than based on the rule of law. It only plays a consulting role and focuses on microprudential issues and cannot be considered to be an effective surveillance tool of international financial stability. ${ }^{176}$

\subsubsection{The OECD}

The Organization for Economic Co-operation and Development (OECD) originated in 1948 as the Organization for European Economic Co-operation (OEEC) to help administer the Marshall Plan. In 1961, the OEEC was transformed into the OECD and its mandate was extended to non-European states. Currently the organization consists of 34 states, amongst which almost all are developed countries (Europe, North America and Australia). Its focus is to stimulate economic progress and world trade. It is a forum of countries committed to democracy and the freemarket economy, providing a platform to compare policy experiences, seek answers to common problems, identify good practices and co-ordinate the domestic and international policies of its members. The organization's structure includes a Secretariat, a Council, Substantive Committees and special bodies. Its limited mandate (focused on trade), limited resources (in terms of budget and staff) and, above all, its limited membership

176 G. Hufbauer, D.D. Xie, op. cit., at p. 952. 
are the primary reasons why it is not considered to be a candidate for international financial supervisor.

\subsubsection{The Joint Forum}

The Joint Forum is an international group bringing together financial regulatory representatives from the banking, insurance and securities sectors. It works under the international bodies for these sectors, the Basel Committee on Banking Supervision (BCBS), the International Organization of Securities Commissions (IOSCO) and the International Association of Insurance Supervisors (IAIS). The group develops guidance and principles, and identifies best practices that are of common interest to all three sectors.

The BCBS provides a forum for regular cooperation on banking supervisory matters. Its objective is to enhance the understanding of key supervisory issues and to improve the quality of banking supervision worldwide. The Committee is further sub-divided, each of which subdivision has specific task forces to work on specific implementation issues: the Standards Implementation Group, the Policy Development Group, the Accounting Task Force and the Basel Consultative Group. ${ }^{177}$ The most important achievement of the BCBS in recent years has been the issuing of the Basel III. It is a comprehensive set of reform measures, developed to strengthen the regulation, supervision and risk management of the banking sector. ${ }^{178}$ It is scheduled to be introduced from 2013 until 2019 (originally 2015).

The IAIS is a voluntary, membership-driven, non-profit organization of insurance supervisors and regulators from all over the world, domiciled in Basel, Switzerland. The mission of the IAIS is to promote global supervision of the insurance industry. The IAIS issues global insurance principles, standards and guidance papers, provides training and support on issues related to insurance supervision, and organizes meetings and seminars for insurance supervisors. ${ }^{179}$ It is not an international organization and possesses no supervisory powers itself.

177 The official website of the BCBS, http://www.bis.org/bcbs/about.htm [last accessed on 30.11.2013].

178 H.S. Scott, op. cit., at pp. 768-773.

179 The official website of the IAIS, http://www.iaisweb.org/About-the-IAIS-28 [last accessed on 30.11.2013]. 
The IOSCO is an association of organizations that regulate the world's securities and futures markets. The organization's role is to assist its members to promote high standards of regulation and to act as a forum within which national regulators cooperate with each other and other international organizations. IOSCO is structured into a number of committees that meet several times per year at different locations around the world and it has a permanent secretariat based in Madrid. ${ }^{180}$

The Joint Forum provides an excellent consultative group and sets important standards for specific financial sectors. It would make a great advisor of an organization supervising international finance. It cannot replace it though, since it has no such mandate, nor the necessary resources.

\subsubsection{Other Candidates}

Apart from the above mentioned international financial organizations and forums, there are many others: International Accounting Standards Board (IASB), International Federation of Accountants (IFAC), Committee on Payments and Settlements Systems (CPSS), Financial Action Task Force, International Accounting Standards Committee (IASC), International Corporate Governance Network (ICGN), International Organization of Supreme Audit Institutions (INTOSAI), International Competition Network. But those organizations are either exclusive clubs for the wealthy states or universal organizations, but still administered mostly by wealthy states, lacking transparency, accountability and equal representation. ${ }^{181}$ They merely set voluntary professional standards, do not enact laws, have no enforcement mechanisms, have small staff and very limited resources. They could be useful as advisors, but are unable to take on supervisory task itself.

\section{Conclusions}

The world crisis of 2007-2009 proved, once and for all, that states working separately can neither prevent nor fight financial turmoil.

180 The official website of the IOSCO, http://www.iosco.org/about/pdf/IOSCO-FactSheet.pdf [last accessed on 30.11.2013].

181 Ch. Brummer, op. cit., at p. 642. 
Keeping this in mind, one should seek a solution at an international level. There are two possible options to fix this problem. One is to burden an international organization with the task of international financial surveillance. The other is to do the same through an international agreement. The latter however seems to still require the establishment of some type of international body, to monitor and administer observance of the treaty. An additional flaw is that it deprives the system of an essential factor - flexibility and quick reactions.

Choosing an international organization to undertake the job is not an easy task. None of the existing ones is tailor-made for it. However, adjusting one of them seems more reasonable and cost-effective than experimenting with the establishment of a new one. There already exist a few organizations which deal with international economic law. The IMF, the World Bank and the WTO are the most obvious options. Each of them successfully manages one part of international economic law, namely international monetary law, international development law and international trade law, respectively. Apart from them, there are several other minor organizations, which cannot be considered serious candidates, due to restrictions in their mandates, memberships, budgets, staff and above all legitimacy.

In the view of this author, the best suited organization to perform international financial supervision is the IMF. There are several reasons that support this opinion. First, the IMF already deals with major economic crises of a similar financial nature - monetary. Second, it is has proved in the past to be capable of adjusting to a new situation and mission. Its mandate, experienced staff and flexible structure would require fewer modifications than any other major international organization. However, it should be noted, that five years after the gravest financial disaster of our generation, no major reform of the international financial system has been undertaken. This fact calls into question the intention of states to submit to any financial supervisor. 